\title{
Lagu Separuh Aku karya Band Noah: Sebuah Tinjauan Karya Musik Ringan
}

\author{
Titis Setyono Adi Nugroho
}

Alumni Jurusan Musik, FSP ISI Yogyakrta; email: tisbethai@yahoo.com

\begin{abstract}
The Separuh Aku song which was written by the Noah band and released in September 2012 has briefly gained its popularity in public. The success is not merely caused by its song strength but also by its interrelationship with various supporting elements. Through the analytical descriptive-qualitative method, this study is aimed at uncovering the secret of song strength and other supporting aspects behind its brief gained popularity. Among several theoretical concepts that were utilized in discussing this research, the topic was first of all taken from Adorno's light musik classification, industrial domination of pop musik culture and its consumption. The other two concepts were from the Frith's non-poetical song lyric and Burton's power of media. Based on those concepts several research outputs have resulted. Pop musik that can be classified as the light musik is supported by simple lyric writing that could easily be accepted by all public layers, especially workers class who worked under company's timeline pressure and targets. In addition, the power of lyric meaning which conditioned with the listener's psychological situation has emerged a certain musikal expression. It is happened, for example, through a tune as an effort on what is experienced by the audience. The expression has taken part in song dissemination effort to other consumers' ears. At the other hand, the improvement of song popularity can also be formed through media announcement concerning song as well as other related aspects. For example is the popular case announcement of Ariel Noah, as a singer. This is called as the human interest aspect concepts. This study concludes that one among many aspects of song/ pop musik populatrity achievement can be seen from its the power of form and content of the song as well as supports from various medias.
\end{abstract}

Keywords: Pop musik, popularity; Noah; light musik

\begin{abstract}
Abstrak
Lagu Separuh Aku karya band Noah yang dirilis pada September 2012 secara singkat populer di masyarakat. Ini semata-mata bukan hanya terletak pada kekuatan lagu, melainkan adanya keterkaitan berbagai elemen pendukungnya. Dengan menggunakan metode kualitatif deskriptif analitik, penelitian ini bertujuan untuk mengetahui kekuatan-kekuatan lagu pop dan hal-hal lain di balik kecepatan laju popularitasnya. Dalam membedah permasalahan ini digunakan beberapa teori/ konsep, yakni dari Adorno tentang klasifikasi musik ringan, dominasi industri budaya dan konsumsi musik pop, Frith tentang lirik lagu bukan puitis, serta Burton tentang kekuatan media. Berdasarkan konsep-konsep tersebut didapatkan sejumlah hasil penelitian. Musik pop yang termasuk kedalam klasifikasi musik ringan yang didukung penciptaan lirik sederhana dengan mudah diterima oleh semua lapisan masyarakat, terlebih lagi oleh kaum pekerja yang bekerja dibawah tekanan waktu dan target perusahaan. Kemudian melalui kekuatan makna lirik yang terkondisikan dengan keadaan psikologis pendengar timbul suatu ekspresi musik, misalnya lewat nyanyian sebagai upaya penghiburan atas apa yang dialami penikmat. Suatu ekspresi tersebut tanpa mereka sadari ikut andil dalam upaya penyebaran lagu ke telinga konsumen lain. Di sisi yang sama peningkatan popularitas lagu juga dapat dibentuk melalui pemberitaan media, baik pemberitaan tentang lagu maupun hal-hal lain, misalnya melalui pemeberitaan kasus Ariel Noah, hal ini disebut dengan konsep aspek human interest. Melalui penelitian ini didapatkan kesimpulan bahwa salah satu pencapaian popularitas sebuah lagu/musik pop dapat dilihat dari kekuatan bentuk dan isi lagu serta dukungan dari berbagai media.
\end{abstract}

Kata kunci: Musik pop; popularitas; Noah; musik ringan

\section{Pengantar}

Pada tanggal 16 September 2012 Noah mengeluarkan album terbarunya. Dalam lounching album tersebut, band ini memilih Melbourne, Hongkong, Kuala Lumpur, Singapore, dan Jakarta sebagai tempat konsernya yang bertajuk Noah Born to Make History. Tidak tanggung-tanggung konser 
promo album tersebut diadakan dalam tempo 24 jam. Penampilan dari Noah memang telah ditunggu-tunggu oleh para penggemar-nya, tentunya mengingat band ini telah melakukan rehat dari aktifitas musik selama kurang lebih 2 tahun. Sebelumnya Noah telah tampil secara format akustik di acara Inbox SCTV untuk mempromosikan single terbaru mereka Separuh Aku.

Lagu yang diciptakan oleh David ini termasuk salah satu lagu dalam album terbaru Noah, Seperti Seharusnya. Sebagaimana pernyataan David:

"Lagu itu idenya dari pengalaman orang lain, curahan hati teman. Dari situ saya tulis lagu itu menunjukkan bahwa aku juga merasakan perasaan yang sama dengan temanku."

Pada kesempatan yang sama Ariel mengatakan: "Ini lagu bagus. David yang ngerjain sampai finishingnya. (republika.co.id, 2015)

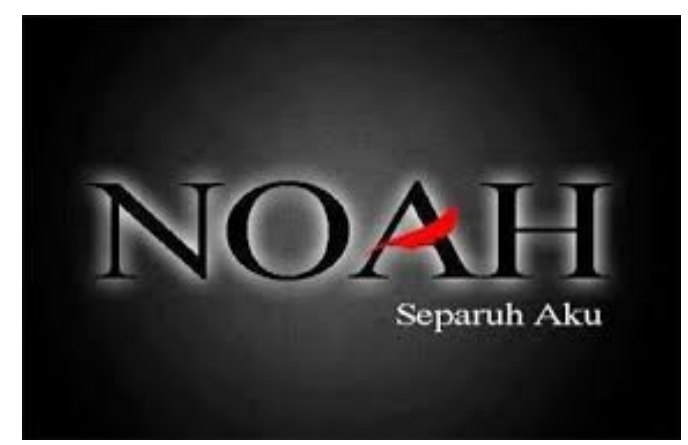

Ilustrasi. 1.

Simbol nama Noah dan judul single hit lagu Separuh Aku

Sebagaimana prediksi beberapa pengamat musik tanah air, lagu ini mendapatkan posisi tangga lagu teratas dari progam-progam acara dalam hitungan hari, baik televisi maupun radio. Situasi yang sama dinyatakan web resmi Noah bahwa video klip lagu Separuh Aku yang diunggah ke Youtube berhasil menyedot penonton kurang lebih sebanyak dua juta viewers dalam waktu empat minggu saja (Noah-site.com, 2015). Selain itu, lagu tersebut menjadi Twitter Trending Topic versi World Wide bahkan mampu mendominasi lagu-lagu bergenre sama yang sedang in di Indonesia pada saat itu. Fakta di lapangan juga menunjukkan lagu Separuh Aku berhasil masuk dalam nominasi-nominasi dari beberapa kategori penghargaan AMI Award 2013, diantaranya adalah kategori Grup Pop terbaik, Lagu Terbaik, Penata Musik Terbaik, dan Karya Produksi Terbaik (okezone.com, 2015). Bukan hanya itu, Separuh Aku juga menginspirasi munculnya sinetron Separuh $A k u$ yang di bintangi selebritas papan atas seperti Asmiranda. Sinetron produksi SinemArt ini menggunakan lagu Separuh Aku untuk dijadikan soundtrack beberapa adegannya (wikipedia.org, 2015).

\begin{tabular}{l}
$\begin{array}{l}\text { Twitter Trending Topics - } \\
\text { Worldwide }\end{array}$ \\
$\begin{array}{l}\text { \#20PeopleWholWantToMeet } \\
\text { \#everyonelikesitbutme }\end{array}$ \\
\hline \#HapeEsiaCuma306rb \\
\hline N0AH-Separuh Aku \\
Kadinlarda itici Özellikler \\
\hline SPY Teaser
\end{tabular}

Ilustrasi. 2.

Posisi lagu Separuh Aku pada Twitter Trending topic versi Worlwide (Ilustrasi. google, 2015).

Fenomena popularitas singkat lagu Separuh Aku dianggap tidak terlepas dari peristiwa atau permasalahan yang menimpaAriel. Keterkaitan permasalahan yang menimpa Ariel dianggap menjadi sarana aji mumpung dalam strategi promosi lagu tersebut.

Ariel tersandung kasus video asusila bersama dengan dua orang selebritas papan atas, yakni Cut Tari dan Luna Maya. Kasus tersebut berakhir di pengadilan dengan putusan kurungan penjara selama 4 tahun oleh hakim kepadanya. Sebaai akibatnya Noah menjalani hibernasi selama masa kurungan si vokalis yang kemudian diakhiri dengan merilis single Separuh Aku tersebut. 


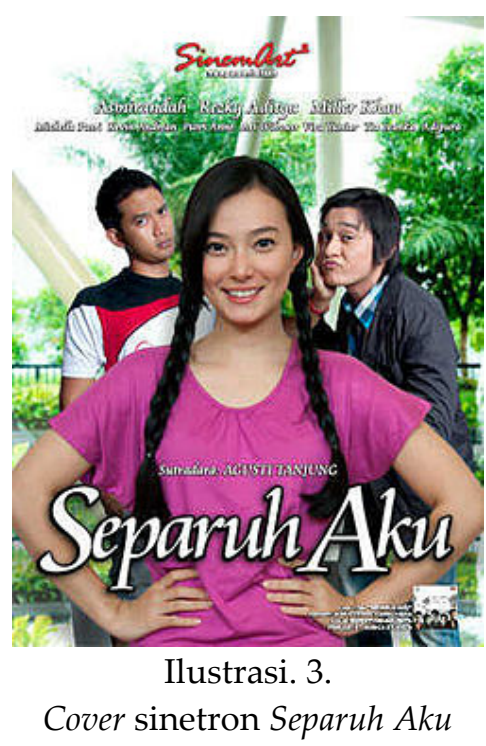

Kasus Ariel sendiri bagi penulis dianggap sebagai sebuah teori konspirasi pemasaran. Kasus ini seperti memanfaatkan musibah yang akhirnya menjadi sebuah anugerah bagi Noah dan industri musik yang menaungi band tersebut. Anggapan ini penulis kaitkan dengan apa yang terlihat di media layar kaca maupun cetak. Sorotan media dianggap penulis juga turut andil dalam meramaikan strategi pemasaran prapeluncuran lagu Separuh Aku melalui peliputan perkembangan kasus Ariel secara intens. Dalam hal ini, sosok Ariel diilustrasikan sebagai objek yang memprihatinkan dan selayaknya mendapat rasa belas kasih.

Meskipun kasus Ariel tersebut diasumsikan penulis sebagai pendukung popularitas lagu Separuh $A k u$, namun penelitian ini berupaya untu tetap mengedepankan objektifitas dengan mengupas kekuatankekuatan yang terdapat dalam lagu pop. Bahwasanya tidak memungkinkan sebuah lagu pop tanpa memiliki kekuatan baik dalam bentuk dan isi mampu mempengaruhi minat dan selera masyarakat konsumen untuk menggandrunginya. Beberapa teori yang didalamnya mengandung konsep-konsep maupun definisi-definisi mengenai musik populer khususnya musik/ lagu pop akan menjadi rujukan analisa penelitian. Meskipun sudah banyak terdapat literatur kajian musik populer melalui lagu-lagu pop, tapi penulis berharap tulisan ini menjadi penambah khasanah tentang kajian musik populer dengan studi kasus lagu pop yang belum pernah disinggung pada literatur-literatur sebelumnya yakni lagu Separuh Aku karya Noah.

Sebagaimana konsep mapun teori yang dihadirkan untuk membedah studi kasus, maka tujuan penulis berupa ingin menunjukan sisi kekuatan lagu/musik popular yang berkembang di masyarakat dewasa ini dan beberapa elemen yang mendukung terbentuknya kepopularitasan lagu. Maka dengan adanya tulisan ini penulis berharap pembaca mendapatkan manfaat tambaan pengetahuan mengenai kekuatan lagu/ musik pop dan elemen pendukung popularitas lagu melalui studi kasus yang dihadirkan, yakni lagu Separuh Aku karya band Noah.

Penelitian tinjauan karya musik populer dilakukan dengan menggunaan penelitian kualitatif dengan metode deskriptif analitik melalui penjabaran studi kasus pada sebuah karya musik. Pemilihan metode ini dipilih karena penilitian fokus kepada fakta-fakta yang nantinya dijabarkan dalam memahami fenomena atas apa yang dialami oleh subjek/ penulis. Begitu juga dengan karakteristik penelitian kualitatif yang mana menurut Suharsimi dkk. salah satu tujuan penelitian kualitatif adalah untuk mencari dan memahami makna konteks dari data yang diteliti (Kuntjojo, 2009:13). Metode deskriptif analitik banyak menggunakan kata-kata, bukan angka-angka yang kemudian diuraikan sekaligus dianalisis sesuai dengan tujuan penelitian sehingga menghasilkan simpulan. Dengan menggunakan metode ini diharapkan objek dapat diberikan makna secara maksimal (Ratna, 2010:336-337). Uraian pengertian metode tersebut sejalan dengan kajian pada penelitian ini nantinya.

Sesuai hakikatnya objek adalah keseluruhan permasalahan yang dijabarkan dalam penelitian, sebagai bentuk pasif, tidak 
terbatas, meliputi benda-benda, baik konkret maupun abstrak (Ratna, , ibid., 2010: 135). Dalam kasus ini objek penelitian berupa benda seni audio, yakni sebuah karya lagu Separuh Aku yang dipopulerkan oleh band Noah.

Berdasarkan penuturan Hamidi, dalam penelitian kualitatif peneliti berposisi sebagai instrumen itu sendiri (2004:14). Jadi pada penelitian ini peneliti bertindak sebagai instrument penelitian.

Data diuraikan dengan model analisa bentuk dan isi dengan gejala yang dapat dirasakan secara jasmaniah yakni indra pendengaran dan penglihatan serta fungsi atau pun makna objek yang nantinya dapat dijelaskan melalui kata-kata mapun kalimatkalimat narasi sebagai analisa wacana (Ratna, 2010:340-343).

\section{Pembahasan}

\section{Tinjauan Pustaka dan Landasan Teori}

a. Tinjauan Pustaka

Kajian mengenai musik pop tentunya telah banyak dilakukan melalui penelitianpenilitian para ahli dengan berbagai topik dan sudut pandang tertentu. Sebagai tujuan untuk menjaga dan memperkuat keaslian kajian penelitian ini, maka diperlukan adanya suatu tinjauan pustaka. Kegiatan ini tetap mengarah kepada hal-hal atau topiktopik yang berhubungan dengan kajian penelitian. Beberapa tinjauan pustaka yang diambil meliputi beberap jurnal karya ilmiah lain.

Penelitian Hananto (2011) terhadap karya Duarte yakni Sonatina Op. 15 untuk Flute dan gitar mengupas tentang harmoni dan dinamika yang dimunculkan. Analisis tersebut didasarkan pada kecenderungan penyimpangan bentuk baku dalam perkembangan sonatina pada awal abad ke 20 . Pemakaian judul Sonatina populer dianggap hanya sebagai suatu model historik semata, karena struktur bentuknya merupakan komposisi instrumental yang mandiri dalam konteks musik abad ke 20. Dalam analisanya,
Hananto melihat terdapat beberapa watak/gaya musik jazz diantaranya polimetrik dan poliritmik. Fokus penelitian ini lebih menitikberatkan pada analisa struktur lagu yang pada dasarnya mempunyai kemiripan dengan analisa bentuk dari kajian penulis namun melalui pisau teori yang berbeda.

Hermintoyo memaparkan tentang implikatur metafora dalam lirik puitis lagu populer di Indoensia. Implikatur tersebut dapat dipahami melalui penanda dan petanda dari simbol-simbol yang dipakai pengarangnya. Pemahaman metafora dalam lirik lagu - puitis - tidak lepas dari kode bahasa, sastra, maupun kode budaya. Berdasarkan pemahaman simbol dalam implikatur metafora dapat diidentifikasi metafora serenada (percintaan), elegi (kesedihan), satir(sindiran), ode (kepahlawanan), himne (ketuhanan), dan pasturale (pemandangan). Terlihat dari hasil penelitian Herminto lebih pada analisa lirik lagu yang cenderung bernuansa puitis, hal ini berseberangan dengan studi kasus penelitian penulis yang mana penggunakan liriknya merupakan kata-kata sederhana dan sangat mudah dicerna oleh awam sekalipun.

Melalui penelitiannya, Fikri (2016) mengungkap perkembangan dan pengaruh budaya musik pop terhadap musik keroncong. Dijabarkan olehnya bahwasanya musik pop dipolitisasi sebagai kekuatan pelestarian dan kelanggengan musik keroncong di ranah industri dan masyarakat. Sebagai bentuk politisasi dan aktualisasi eksistensinya tampak pada penggunaan lagu pop yang diaransemen ke dalam nuansa musik keroncong. Penelitian tersebut dalam pandangan penulis lebih mengandung pemahaman tentang pengunaan lagu-lagu pop sebagai media pelestarian musik keroncong di Indonesia.

Berdasarkan beberapa kajian yang sudah dipaparkan di atas, tidak terdapat kemiripan bahkan suatu unsur plagiasi dalam penelitian ini. Penelitian pada lagu Separuh $A k u$ dengan mengkaji bentuk dan isi 
musiknya sangat tidak terdapat pada kajiankajian tersebut.

b. Landasan Teori

Sebagai bahan analisa penelitian, penulis berupaya mengkaji popularitas lagu Separuh Aku karya band Noah dengan berdasar beberapa konsep maupun definisi dari teori-teori tokoh yang membahas kajian musik pop, diantaranya adalah Adorno, Frith dan Burton.

Bagi Adorno, kandungan yang terdapat dalam musik pop didefinisikannya sebagai musik ringan. Hal ini sesuai dengan klasifikasinya sbb (Budiarto, 2001:77-78).

1) Komposisi musik mengikuti polapola atau kerangka yang biasa, yang digayakan.

2) Sedikit sekali orisinalitasnya.

3) Struktur keseluruhan tidak tergantung pada detil-detil. Keseluruhan tidak diganti oleh detildetil, namun lebih me-rupakan potongan-potongan yang disatukan.

4) Struktur melodis sangat kaku dan kerap diulangi.

5) Struktur harmoni mengan-dung seperangkat skema. Fakta harmoni yang paling primitif ditekankan.

6) Komplikasi tak mempengaru-hi struktur komposisi dan tak mengembangkan tema.

7) Ada penekanan dalam kombinasi efek-efek dalam suara, timbre, nada, hentakan, dan irama.

8) Improvisasi dinormalkan atau direlatifkan. Kalau musik ini difungsikan, misalnya untuk menari, anak-anak hanya dapat bergoyang dalam ke-rangka yang sempit.

9) Detil-detil dapat dipertukar-kan karena hanya memainkan fungsi sebagai roda bergerigi sama.

10) Meneguhkan norma-norma mengenai apa yang menentukan intelegibilitas dalam musik agar tampak baru dan orisinal. Ini bertujuan agar selalu menarik konsumen.

Selanjutnya, menurut Adorno, musik ringan yang dihasilkan oleh industri budaya didominasi oleh dua proses, yakni standardisasi dan individualisasi semu. Di sini gagasannya adalah lagu-lagu pop makin lama makin terdengar mirip satu sama lain. Lagulagu itu semakin banyak dicirikan oleh suatu struktur inti, yang bagian-bagiannya dapat dipertukarkan satu sama lain. Namun demikian inti-inti disembunyikan oleh tambahan sampingan, kebaharuan atau variasi gaya yang direkatkan pada lagu-lagu tersebut sebagai tanda kekhasannya yang sudah diduga. Standardisasi merujuk pada kemiripan mendasar diantara lagu-lagu pop, sedangkan individualisasi semu merujuk pada perbedaan-perbedaan yang sifatnya kebetulan.

Standardisasi mendefinisikan cara bagaimana industri budaya mengatasi berbagai macam tantangan, orisinalitas, autentisitas, ataupun rangsangan intelektual dari musik yang dihasilkannya, sementara individualisasi semu akan memberikan umpannya, keunikan atau kebaruan nyata dari lagu tersebut bagi konsumen. Standardisasi mengandung pengertian bahwa lagu-lagu pop makin mirip satu sama lain, dan bagian-bagian, bait-bait maupun akornya semakin dapat saling dipertukarkan, sementara individualisasi semu menyamarkan proses ini dengan menjadikan lagu-lagu itu semakin bervariasi dan berlainan satu sama lain (Strinati, 2009:112-113).

Adorno menyatakan bahwa musik pop mendorong pendengaran pasif. Konsumsi musik pop senantiasa pasif dan repetitif, yang menegaskan dunia sebagaimana adanya. Musik pop punya korelasi non produktif dengan kehidupan di kantor atau di pabrik. Kebosanan dan ketegangan kerja mengantar laki-laki dan perempuan pada penghindaran terhadap 
penggunaan energi fisik dan mental di waktu luangnya. Menampik kesenangan baru di waktu kerja, dan terlalu lelah untuk menikmatinya di waktu luang, mereka sangat membutuhkan stimulan. Musik pop memuaskan apa yang diidamkan konsumennya (Storey, 2007:118-119).

Dalam upaya menegaskan dunia sebagaimana adanya, musik pop menggunakan lirik sebagai kekuatan utamanya. Menurut Frith, penulis lirik musik pop bekerja berdasarkan kewajaran bahasa. Mereka membuat kata-kata dan frase kata yang paling lumrah. Segera tampak penuh acuan dan lelucon lihai. Dengan susunan verbal dan klise yang baik, menambahkan pemahaman kita akan bahasa yang umum. Lagu-lagu pop berkenaan dengan kata-kata. Lagu pop memberi pendengar cara baru melafalkan kelumrahan wacana sehari-hari. Dengan kata lain, lagu-lagu pop punya kekuatan untuk mejadikan bahasa biasa jadi intens dan vital. Selain membentuk pandangan pendengar tentang dunia sebagimana adanya, Frith menambahkan bahwa kata-kata dalam lirik beresonansi membawa sentuhan fantasi ke dalam penggunaan kebiasaan kita atas kata-kata tersebut. Lagu-lagu pop bekerja dengan tepat sepanjang lagu-lagu itu bukan sajak. Kedangkalan lagu pop dimunculkan orang, secara umum, tidak menjelaskan melainkan mendorong. Mereka memberi pemerataan emosional terhadap frase-frase yang lazim yang dimiliki hampir semua orang untuk mengekspresikan perhatian/keprihatinan mereka sehari-hari. Bahasa yang mengepung pendengar tiba-tiba tampak terbuka, jika tidak bisa berbicara lewat sajak, pendengar bisa mengutarakan lewat lagu pop (Storey, 2007: 136-137).

Lirik yang beresonansi ke telinga pendengar tidak mungkin akan sampai tanpa perantara media. Media berkekuatan dalam mengembangkan secara masif bagi lirik dan tentunya lagu pop tersebut. Sama halnya dengan lirik, kekuatan media yang secara umum didasarkan atas uang, kekuatan hukum, dan manajemen menjadi kekuatan membentuk produk yang memiliki kemampuan untuk mengkomunikasikan ideologi, nilai, dan ide. Ide-ide tersebut nantinya memiliki kekuatan untuk membentuk pandangan-pandangan audien (Burton, 2006: 72). Pandangan-pandangan ini dapat dibentuk melalui peristiwa-peristiwa yang dirangkum dalam sebuah berita maupun kisah yang diberitakan.

Alasan untuk memberikan perhatian pada berita dalam kajian media merupakan sumber utama informasi tentang dunia dalam hal geografi dan politiknya. Namun berita bukan sesuatu yang lengkap dan terbentuk secara penuh melainkan diciptakan. Organisasi-organisasi dalam berita menetapkan suatu agenda topik yang membentuk wacana. Para editor memilih berita, dan dengan demikian memilih suatu agenda item yang kemudian kita saksikan tentang apa yang penting di dunia hari ini atau minggu itu. Nilai-nilai berita berkaitan dengan berbagai topik yang dinilai sebagai para pembuat berita layak untuk diberitakan karena nantinya akan sejalan dengan skema presentasi topik ke publik. Pemilihan nilai personalitas tokoh publik lebih diprioritaskan daripada banyak kisah yang lain karena kisah tersebut secara otomatis cocok dengan apa yang disebut sebagai aspek human interest. Selanjutnya prioritas diberikan pada item-item berita yang jelas akan memiliki suatu kontinuitas ketika kisah mulamula berakhir (Burton, 2006: 153-156).

\section{Adorno tentang Klasifikasi Musik Ri- ngan}

Lagu Separuh Aku karya band Noah dapat dikategorikan sebagai musik ringan. Pernyataan ini berdasarkan klasifikasi musik ringan oleh Adorno seperti yang sudah dipaparkan di atas. Berdasarkan klasifikasi tersebut, maka lagu Separuh Aku dapat dianalisa sebagai berikut. 
Pertama, lagu Separuh Aku mengikuti pola-pola atau kerangka yang biasa digunakan pada lagu-lagu pop pada umumnya yaitu misalnya tema A-B-C. Meskipun lagu ini secara luar dapat dikatakan A$\mathrm{A}^{\prime}-\mathrm{B}-\mathrm{B}^{\prime}-\mathrm{C}-\mathrm{C}^{\prime}$, namun lebih mendekati seperti yang sudah diterangkan pada paragraf sebelumnya yaitu A-B-C. Tema A bisa dilihat dari bait pertama dan keempat pada liriknya. Pengulangan intonasi Yang terjadi lagi kisah lama yang terulang kembali pada lirik Kau terluka lagi dari cinta rumit yang kau jalani pada bait pertama tidak bisa disebut sebagai pengulangan tema dikarenakan masingmasing masih terhitung 4 birama. Hal ini hanya disebut sebagai kalimat tanya dan jawab, meskipun kalimat jawab tetap dirasa perlu adanya pertimbangan, dikarenakan akor tidak berhenti di akor I, melainkan sama-sama berhenti di akor V.

Tema B hampir serupa dengan tema A, terjadinya pengulangan yang juga hanya disebut dengan kalimat tanya-jawab. Kalimat tanya Jawab dari tema B lebih jelas dikarenakan pada 4 birama awal dan 4 birama akhir diakhiri dengan akor yang berbeda. Namun layaknya tema jembatan, birama terakhir dalam tema ini disuguhkan dengan akor III mayor yang difungsikan sebagai akor $\mathrm{V}$ bersifat modulasi. Kemudian tema $C$ serupa dengan tema-tema sebelumnya, adanya kalimat tanya-jawab yang terdengar seperti pengulangan tema. Tema C sudah mengalami modulasi nada dasar yang semula 2\# menjadi 5\#. Pengulangan tema A pada di bait ke 4 lirik mengembalikan tonal ke 2\#. Tidak ada sedikitpun perubahan bentuk musik pada pengulangan tema A dalam bait keempat ini, hanya pada kalimat liriknya saja.

Kedua, orisinalitas pada lagu Separuh $A k u$ seakan-akan ada, namun ternyata semu hanya disamarkan oleh intro ritmis perkusi dalam hal ini drum set disusul melodi sederhana dari piano, gitar dan vokal "huu" yang diulang-ulang sehingga menjadi karakter/identitas bentukan. Meskipun terkesan orisinal, namun sebagian besar musik pop (ringan) mempunyai identitas yang sama. Jika kita mendengarkan beberapa lagu pop bernuansa sejenis dengan lagu Separuh Aku, maka akan menemukan kesamaankesaaman. Kesamaan yang mencolok biasanya segi tema. Bumbu-bumbu kecil orisinalitas semu lagu Separuh Aku terletak dalam segi patren beat drumt, piano, gitar, vokal "huu" dan sound. Semua bumbu tersebut seakan menjadi pembeda dengan lagulagu pop sebelum-sebelumnya.

Ketiga, struktur keseluruhan tema pada lagu Separuh $A k u$ tidak tergantung pada detil-detil karena tema A-B-C dalam lagu Separuh Aku dapat dipotong dan ditukar susunannya sedemikian rupa tanpa takut akan merubah identitas lagu. Pertukaran lirik bait per bait pun juga tidak serta merta menimbulkan perusakan struktur tema. Misalnya saja susunan bait 1-2-3-4-5 diubahubah tetapi tanpa mengubah lirik dan melodi yang melingkupinya, hasilnya tidak akan terjadi keganjilan yang signifikan, jika pun ada hanya permasalahan akor yang menjadi jembatan menuju modulasi. Sebenarnya, hal ini pun tidak terlalu masalah dalam musik pop dan tidak akan mengganggu identitas lagunya.

Jika terdapat pemotongan bait, atau tidak adanya pengulangan bait hanya akan menimbulkan sedikit permasalahan pada durasi. Masalah tersebut pada dasarnya merupakan permasalahan efek psikologis pendengar yang berimbas pada kuantitas penjualan ke konsumen. Pada umumnya produk lagu pop berdurasi antara 2-5 menit, demikian pula dengan lagu Separuh $A k u$ yang hanya berdurasi 4 menit 30 detik. Berdasarkan pengalaman penulis, lagu yang memiliki durasi kurang dari 5 menit menimbulkan efek penasaran dan nagih atas lagu tersebut, namun sebaliknya jika sebuah lagu berdurasi lebih dari 5 menit akan menimbulkan efek cepat bosan. 
Seorang produser musik pop memberlakukan standarisasi durasi lagu bertujuan untuk operasi perdagangan. Durasi masing-masing tema terlebih lagi pada bagian $\mathrm{C}$ - refren - biasanya merupakan bagian terpenting dalam politik perdagangan mereka. Bagian C dapat diperjualbelikan, misalnya sebagai RBT (Ring Back Tone) dalam mekanisme Mobile Phone. Mereka - produser dan band - selalu menekankan perhatian penuh terhadap tema $C$ ini. Jika melihat pada lagu lain misalnya, lagu Goyang Dumang yang dipopulerkan oleh Cita Citata jelas sekali teridentifikasi mementingkan bagian refren, atau lagu We Are Young yang dipopulerkan oleh Fun yang kemudian menjadi jingle salah satu iklan televisi komersial.

Keempat, klasifikasi kekakuan dan repetisi struktur melodis sangat berlaku pada hampir diberbagai birama lagu Separuh $A k u$ dan potongan tema. Mengenai klasifikasi ini sudah dijelaskan dalam klasifikasi pertama tentang tema A-B-C. Pada lagu ini pengulangan tema $\mathrm{A}$ terjadi di bait empat dan bait/tema dibagian refren (tema C) yang muncul kembali hingga tiga kali. Struktur melodi yang kaku ditunjukkan pada improvisasi pengulangan tema A tersebut. Meskipun pengulangan ketiga pada tema $\mathrm{C}$ terdapat satu nada yang diubah, namun masih tetap dikatakan kaku dan miskin akan struktur melodi. Perubahan nada tersebut terdengar pada kata dengar dalam kalimat dengar laraku. Berawal dari nada do-re berubah menjadi fa-fa.

Perlu digaris bawahi kekakuan pola melodi dan seringnya pengulangan menandai berlakunya fungsi psikologis pendengar. Repetisi struktur melodi dan tema difungsikan sebagai proyek memori konsumen, dimana sebuah melodi yang kaku dan sederhana atau tema yang diulang sebanyak dua kali atau lebih akan dengan mudah dihapal oleh pendengar. Semakin banyak orang menghapal dan kemudian dengan sadar maupun tidak sadar menyanyikan sebuah lagu secara tidak langsung berdampak terhadap popularitas lagu tersebut. Semakin lagu menjadi populer semakin lancar pula permintaan konsumen atas aksi panggung artis yang mempopulerkan lagu tersebut dan kemudian berimbas pada pendapatan ekonomi oleh berbagai pihak yang terlibat baik dalam produksi dan pemasaran lagu maupun pemrakarsa aksi panggung artis.

Kelima, lagu Separuh Aku mengembangkan skema harmoni sederhana dimana komposisi musik hanya memainkan harmoni standar. Harmoni empat nada hanya terdapat pada akor dominan7 dan minor7., yakni akor A7 dan Em7 selebihnya menggunakan akor mayor dan minor standar. Pemanfaatan akor primitif inilah merupakan salah satu skema penjualan produk kepada konsumen. Penikmat musik ringan tidak mau dituntut untuk berpikir bahkan untuk menelaah struktur atau bentuk musik dari sebuah lagu. Mereka hanya ingin mendengarkan lagu-lagu pop sebagai hiburan semata, selingan kesibukan kerja, atau sekedar menjadi teman berkendara.

Keenam, tema yang dimunculkan dalam lagu ini hanya A-B-C dan sedikit improvisasi nada dibagian akhir namun tetap tidak mempengaruhi struktur awal tema. Seperti yang sudah diuraikan dalam klasifikasi keempat, perubahan dua nada pada kata dengar tidak mempengaruhi struktur tema $C$ atau refren. Akor dan modulasi yang dimunculkan juga sama, masih mempergunakan tangga nada $5 \#$ atau do $=\mathrm{B}$. Lirik yang berbeda pada tema A yang diulang atau tema $C$ juga tidak memunculkan suatu struktur bentuk musik yang baru.

Ketujuh, adanya penekanan dalam kombinasi efek-efek dalam suara, timbre, nada, hentakan, dan irama pada musik pop berkorelasi dengan ungkapan Adorno tentang individualisasi semu yang memberikan umpannya, keunikan atau kebaruan nyata dari lagu tersebut bagi konsumen. Ungkapan 
Adorno dibuktikan penulis dengan memperdengarkan lagu Separuh Aku kepada anak berumur 5 tahun yang mana lagu tersebut sebelumnya pernah didengarnya. Meskipun hanya intro lagu yang diperdengarkan, namun anak tersebut mampu mengenali judul lagu tersebut dengan cepat. Memori atas lagu Separuh Aku diungkapkannya dengan tanda bunyi-bunyian - struktur repertisi melodi, timbre dan hentakan irama drum - yang membuatnya dapat dengan mudah mengingat judul atau lagu tersebut. Tanda bunyibunyian tersebut kemungkinan memberikan sesuatu yang unik bagi anak berumur 5 tahun sebagai konsumen/ penikmat musik.

Irama dan hentakan-hentakan lebih diproduksi oleh patren bass dan snare pada drum set. Aksentuasi timbul pada ketukan 1 dan 4 dalam sukat $4 / 4$. Hal ini lumrah terjadi pada komposisi musik/lagu pop yang mana aksen ketukan 1 ditimbulkan oleh bass drum sedangkan aksen ketukan 4 ditimbulkan oleh snare drum. Hentakan ini memicu gerakangerakan kecil tubuh pendengar, misalnya gerakan menganggukkan kepala mengikuti patren aksen-aksen yang ditimbulkan, atau gerakan tangan yang mengikuti pukulanpukulan drumer.

Kedelapan, improvisasi melodi gitar pada bagian akhir lagu disesuaikan dengan sukat yang sudah mapan dari awal. Kreativitas improvisasi intrumen yang juga dibatasi seiring dengan dengan lantunan melodi vokal. Hal ini mengokohkan fungsi musik instrumen hanya menjadi pengiring atau pemanis nada-nada vokal. Tanpa adanya instrumen pengiring, lagu masih dapat dinyanyikan tanpa merubah identitas lagu tersebut.

Dinamika, beat, tempo, bahkan nada vokal yang dibuat di lagu Separuh Aku konstan tidak ada perubahan yang signifikan. Meskipun terdapat pengulangan tema tetap saja permainannya juga serupa dengan tema yang sudah dimainkan sebelumnya. Maka jika lagu ini dipergunakan sebagai iringan tarian akan sedikit sekali pola-pola gerakan yang tercipta. Kemungkinan pengulangan pola gerakan akan banyak terjadi, jika timbul hal yang seperti itu maka koreografer dituntut memiliki daya kreativitas yang tinggi.

Kesembilan, detil-detil dalam musik/ lagu pop menurut Adorno dipahami penulis salah satunya sebagai instrumen-instrumen pengiring melodi vokal. Intro lagu yang terdiri dari - secara berurutan - instrumen drum, piano, gitar dan bas gitar, kemudian vokal "huu" jika disusun tanpa memperhatikan estetika komposisi keseluruhan hasilnya tetap tidak akan mengubah identitas lagu. Meskipun detil identitas ditonjolkan oleh instrumen piano, hilangnya intrumen ini pun tidak akan mengubah identitas lagu. melodi dari instrumen piano yang dihilangkan dapat digantikan oleh melodi dan instrumen lain, gitar misalnya. Penghilangan atau pergantian melodi-melodi terhadap masing-masing instrumen hanya akan merubah nuansa lagu.

Terakhir, mengenai pengakuan Ariel terhadap lagu ini serasa mempertegas intelegibilitas orisinal musik. Setiap statement Ariel mengenai lagu Separuh $A k u$ menjadi pengaruh yang luar biasa. Sebelumnya telah diketahui, pemberitaan intens oleh media mengenai kasus yang menimpanya seakanakan menimbulkan sebuah wacana bahwa sosok Ariel ini adalah seperti sosok dewa yang memiliki kharisma dimata penggemarnya. Selama 3,5 tahun pemberitaan media cetak maupun televisi di Indonesia secara tidak langsung mengangkat pamor Ariel dan bandnya. Mulai dari awal munculnya kasus asusila, perilakunya di dalam lapas, hingga resmi sebagai alumni lembaga permasyarakatan Kebonwaru Bandung pun tidak luput dari pemberitaan media. Tak khayal jika kalimat-kalimat yang terucap dari mulut Ariel senantiasa bak dakwah ustad yang langsung diterima dan diamini oleh umatnya.

Dengan melihat keterlibatan media dalam kasus Ariel memberikan keuntungan pihak managemen artis perihal pengorbitan. Jelas saja, hanya selang beberapa hari saja Ariel keluar dari lapas, promosi single Separuh 
Aku dalam album terbaru Noah signifikan meledak dipasar. Tidak tanggung-tanggung hanya dalam tempo tiga bulan saja album terbaru yang didalamnya terdapat lagu Separuh $A k u$ tersebut terjual hingga mencapai 1,2 juta kopi.

\section{Adorno tentang Dominasi Industri Bu- daya}

Diamati dari bentuk musiknya, lagu Separuh Aku karya Noah dapat dikorelasikan dengan standardisasi pernyataan Adorno. Lagu ini tidak jauh berbeda pada lagu-lagu pop pada umumnya, terlebih lagi terhadap lagu-lagu sebelumnya, ketika masih bernama Peterpan. Misalnya pada bentuk tema lagu yang mengusung skema asli A-B-C dengan perkembangan menuju AB-C-A'-C. skema yang menunjukkan di mana A adalah bait satu dan empat, B adalah jembatan atau bait dua, dan $\mathrm{C}$ adalah refren atau bait tiga dan lima. Tema seperti ini merupakan tema yang sering dijumpai dalam musik/lagu pop. Jika dianalisa perbagian tema, dari potongan masingmasing bagian atau bait lirik dapat ditukartukar urutan potongan sesuai dengan dominasi keinginan pencipta. Tidak terkecuali akor-akor yang dimunculkan dapat diganti dengan akor-akor lain karena sifatnya dalam penggunaan harmoni paling sederhana, misalnya saja pada bagian setelah refren pertama akor yang dimunculkan adalah akor vi minor sedangkan lumrahnya adalah akor I major. Pergantian akor tersebut tidak akan menjadikan masalah yang berarti, karena fungsinya hanya ingin mengubah nuansa lagu agar terkesan tidak monoton. Dapat diinterpretasikan juga pergantian tersebut dimaksudkan untuk memunculkan pengulangan intro dalam 4 birama terakhir yang mana sebagai jembatan menuju pengulangan tema A dengan bait/ lirik yang berbeda.

Lagu Separuh Aku secara urutan detilnya bertemakan A-B-C-A'-B-C-C-C'. Urutan tersebut lazim digunakan pada lagu-lagu pop seperti terdapat pada lagu Terimakasih Cinta yang dipopulerkan oleh Afgan. Meskipun tidak benar-benar serupa 100\%, lagu Terimakasih Cinta memiliki kemiripan susunan tema dengan lagu Separuh Aku. Lagu Terimakasih Cinta secara urutan detilnya bertemakan A-B-C-A'-B-C-C'. Perbedaan tema hanya terletak pada pengulangan kuantitas C di bagian akhir lagu. Banyaknya pengulang-an tema tergantung dominasi komposer atau aransir dan produser lagu. Banyak-nya pengulangan tema dikaitkan dengan pertimbangan durasi tingkat jenuh konsumen. Dari segi lirik, susunan bait pokoknya sama secara sempurna. Kesamaan yang banyak ditemukan dalam populasi musik/ lagu-lagu pop terletak pada penggunaan intro sebelum masuk ke tema pokok atau lirik yang akan dinyanyikan.

Kesamaan penggunaan intro dalam sebuah komposisi musik/ lagu-lagu pop menjadikan suatu karakteristiknya, meskipun komposisi di dalam intro itu sendiri beragam bentuknya. Intro lagu Separuh Aku menggunakan permainan ritmis-ritmis drum dan disusul oleh instrumen piano, gitar kemudian vokal dengan artikulasi "huu". Komposisi tersebut dirancang seorang aransir dalam menghasilkan suatu ciri khas pembeda musik/ lagu dari lagu-lagu populer yang sudah ada sebelumnya. Meskipun demikian, identitas tersebut menurut Adorno diibaratkan sebagai individual-isasi semu. Konsep variasi-variasi ritmis drum dan melodi piano yang diulang-ulang pada intro inilah yang menjadi semacam penyamaran kemiripan dengan lagu pop yang lain. Penyamaran ini bertujuan untuk menghadirkan suatu identitas kepada pendengar.

Konsep variasi inilah yang menjadikan salah satu cara industri budaya mengatasi berbagai macam tantangan, orisinalitas, autentisitas, ataupun rangsangan intelektual dari karya musik/lagu yang dihasilkan. Padahal jika dilihat kembali pada intro lagu Yang Terdalam di album Taman Langit 2003 - sewaktu masih Peterpan, tetabuhan ritmis 
yang disusun $95 \%$ serupa dengan intro pada lagu Separuh $A k u$, perbedaan hanya terletak dari penambahan patren hihat. Kemudian tantangan bentuk orisinalitas intro dipertegas dalam pengolahan melodi piano dan artikulasi "huu" pada vokal serta pemilihan karakter timbre yang berbeda dari lagu Yang Terdalam.

\section{Adorno Tentang Konsumsi Musik Pop}

Pandangan Adorno mengenai musik/ lagu pop dan konsumennya dianalogikan dengan kehidupan yang terjadi di kantor atau di pabrik, yang mana musik/ lagu pop mempunyai kemiripan sebagai obat. Musik/ lagu pop menurutnya digunakan oleh pekerja kantoran atau karyawan suatu perusahaan untuk mengobati rasa jenuh atas rutinitas mereka. Layaknya obat, kejenuhan tersebut dapat teratasi dengan hanya mendengarkan musik pop sebagai hiburan di jam padat pekerjaan. Fisik dan mental yang digunakan selama berjam-jam saat bekerja berusaha dihindari dengan relaksasi musik pop. Adanya speaker aktif atau headset pada seperangkat komputer kantor menjembatani seorang karyawan untuk dapat bekerja dengan santai. Contoh yang lain yang biasa ditemui dalam masyarakat urban adalah seorang pembantu rumah tangga yang dengan asik mendengarkan atau pun menyanyikan lagu-lagu pop kesukaannya ditengah kesibukan pekerjaaannya sebagai PRT. Konsumsi musik pop oleh PRT tersebut dianggap pasif dan repetitif dikarenakan pekerja tersebut menganggap musik pop tidak layak untuk menjadi sesuatu yang pantas untuk dipikirkan.

Musik pop dianggap sebagai musik yang ringan, musik selingan, bahkan musik stimulus pembangkit mental dan fisik yang sudah terkuras. Bahwasanya seperti dalam literatur-literatur yang ada, manfaat mendengarkan atau menyanyikan sebuah lagu sebagai salah satu bentuk cara meluapkan ekspresi yang terpendam, dan dapat untuk menambah semangat bagi pelakunya, terlebih lagi lagu pop masa kini semakin mudah untuk dinyanyikan tanpa membutuhkan suatu perhatian khusus terhadap teknik vokal. Hal tersebut dibuktikan dari register vokal dalam lagu Separuh Aku yang memanjakan pendengar kaum pria baik tenor, bariton, atau bas. Ketiga register suara tersebut akan dengan mudah menyanyikan lagu ini, karena hanya berkisar dari nada A sampai nada fis'. Meskipun nada tertinggi adalah fis yang pada dasarnya bukan jangkauan register suara bas - meskipun terdapat beberapa orang dengan register bas yang mampu -, tetapi nada tersebut halal untuk dinyanyikan menggunakan teknik vokal falseto, penggunaan resonansi kepala murni untuk menimbulkan suara tipis bernada tinggi.

Melalui representasi ini, pendengaran pasif tanpa menuntut orang untuk berpikir yang disebabkan oleh konsumsi musik pop dianggap Adorno sebagai bentuk penyelewengan esensi atas intektual musik itu sendiri. Namun terlepas dari esensi tersebut, musik ringan berlirik dengan intonasi vokal yang mudah ditiru untuk dinyanyikan orang awam ternyata memiliki berbagai manfaat fisik dan mental bagi penikmatnya.

\section{Frith tentang Lirik Lagu}

Dalam pandangan Frith, penulis lirik musik pop bekerja berdasarkan kewajaran bahasa. Mereka membuat kata-kata dan frase kata yang paling lumrah. Segera tampak penuh acuan dan lelucon lihai. Dengan susunan verbal dan klise yang baik, menambahkan pemahaman kita akan bahasa yang umum. Lagu-lagu pop berkenaan dengan kata-kata. Lagu pop memberi pendengar cara baru melafalkan kelumrahan wacana sehari-hari. Dengan kata lain, lagulagu pop punya kekuatan untuk mejadikan bahasa biasa jadi intens dan vital. Kata-kata itu selanjutnya beresonansi membawa sentuhan fantasi ke dalam penggunaan kebiasaan kita atas kata-kata tersebut. Lagulagu pop bekerja dengan tepat sepanjang 
lagu-lagu itu bukan sajak. Kedangkalan lagu pop dimunculkan orang, secara umum, tidak menjelaskan melainkan mendorong. Mereka memberi pemerataan emosional terhadap frase-frase yang lazim yang dimiliki hampir semua orang untuk mengekspresikan perhatian/keprihatinan mereka sehari-hari. Bahasa yang mengepung pendengar tibatiba tampak terbuka, jika tidak bisa berbicara lewat sajak, pendengar bisa mengutarakan lewat lagu pop (Burton, 2006: 136-137).

Pengunaan bahasa umum bukan sajak, menurut Frith adalah sebuah kekuatan musik/lagu pop dalam memberikan cara baru melafalkan suatu ekspresi, pemerataan emosi bahkan wacana-wacana yang terjadi di masyarakat. Melalui lirik sederhana, lagu pop berhasil mengubahnya menjadi sesuatu yang vital.

\section{SEPARUH AKU}

Dan terjadi lagi
Kisah lama yang terulang kembali
Kau temukan lagi
Dari cinta rumit yang kau jalani
Aku ingin kau merasa
Kamu mengerti aku mengerti kamu
Aku ingin kau sadari
Cintamu bukanlah dia
Dengar laraku
Suara hati memanggil namamu
Karena Separuh Aku dirimu
Ku ada di sini
Pahamilah kau tak pernah sendiri
Karena aku selalu
Di dekatmu saat engkau terjatuh
Dengar laraku
Suara hati memanggil namamu
Karena Separuh Aku menyentuh laramu
Semua lukamu telah menjadi lirihku
Karena Separuh Aku dirimu

Dari lirik lagu Separuh Aku di atas tampak bahwa penggunaan bahasanya bukanlah bahasa yang bersifat sajak, tapi merupakan bahasa rutinitas. Bahasa ringan yang rutin digunakan dalam percakapan inilah yang dikemukakan oleh Frith sebagai pemerataan emosional. Keseluruhan lirik lagu Separuh Aku dengan jelas menggunakan bahasa sehari-hari dengan topik percintaan atau hubungan istimewa antara sepasang manusia. Tema lirik percintaan mudah sekali ditemukan pada lagu bergenre pop. Lagu bertema cinta seakan menjadi magnet tersendiri dan seperti mengllustrasi.kan kenyataan dunia yang sedang terjadi saat lagu itu diciptakan. Walaupun dunia yang diciptakan dalam lirik lagu biasanya hanya mencakup "aku, kamu, dan dia", tetapi seakan dianggap mewakili apa yang terjadi di setiap sudut permukaan bumi.

Lirik Separuh Aku mengIlustrasikan kisah percintaan yang terjadi di antara tiga orang pelaku. Pelaku pertama atau yang utama adalah penulis lirik, pelaku kedua adalah orang yang dituju oleh penulis lirik, dan pelaku yang ketiga adalah orang lain diantara keduanya. Orang pertama didefinisikan dengan aku, orang kedua dengan kamu atau engkau, dan orang ketiga dengan dia. Ini sesuai dengan interpretasi paragaraf sebelumnya tentang tema cinta pada lagu pop.

Dengan hanya melihat bahasa yang digunakan, makna atau pesan dalam lirik dapat diinterpretasikan secara cepat dan tergolong mudah. Strategi ini yang digunakan penulis lirik musik pop agar karya yang dihasilkan dapat langsung mudah diterima masyarakat luas, bahkan jika lirik yang ditulis mengandung kata-kata yang cocok dengan keadaan yang sedang dialami pendengar saat itu. Jika pendengar yang pada saat itu merasa memiliki keterkaitan makna dengan lirik yang ditulis, maka seolah-olah dirinya menjadi salah satu di antara ketiga pelaku yang dimunculkan. Di sini terlihat peran bahasa pada lirik tersebut menjadi magis atau magnet terhadap konsumen. Pendengar yang tertarik niscaya secara sadar maupun tidak akan menyanyikan lagu tersebut. Nyanyian yang dilontarkan oleh pendengar di ruang publik secara simultan akan beresonansi kepada pendengar lain. Hal ter- 
sebut sejalan dengan salah satu strategi produsen musik/lagu pop dalam meningkatkan popularitas lagu yang tentunya berimbas juga kepada si artis. Seiring meningkatnya popularitas lagu dan artis, maka semakin akan mempengaruhi tingginya profit yang didapat. Jadi, jelas terilustrasikan bagaimana peran penting lirik dengan bahasa rutinitas yang digunakan pada lagu pop pada berbagai hal, seperti meningkatkan popularitas artis dan profit manajemennya.

\section{Graeme Burton Tentang Kekuatan Media}

Kekuatan media dalam membentuk suatu wacana pada kasus Ariel terbilang sukses besar. Malalui kekuatan media, Ariel yang tadinya hanya seorang vokalis band nasional di Indonesia kini bermetamorfosa menjadi layaknya bintang internasional. Melalui rancangan ideologi, nilai, dan ide yang diciptakan oleh kekuatan media meimbulkan efek perkembangan popularitas objek berita. Intensnya pemberitaan kasus Ariel di berbagai media Indonesia, menyebabkan perluasan wacana hingga ke manca-negara, faktanya hingga terdengar oleh Miyabi yang notabene seorang bintang porno dari Jepang. Highline di salah satu media elektronik menyebutkan bahwa Miyabi sampai mencari tahu siapa sosok Ariel dan video asusilanya.

Manajemen organisasi, ide, dan nilainilai dalam kekuatan media mengenai kasus Ariel berhasil menimbulkan anemo masyarakat tentang sosok Ariel. Antusias masyarakat akan Ariel dilihat oleh manajemen artis tersebut sebagai sebuah promo popularitas. Bagaimana tidak, dari mulai munculnya video kasus asusila hingga Ariel keluar dari rutan Kebonwaru Bandung, media gencar memberitakannya. Hal ini yang dimanfaatkan produsen atau manajemen - waktu itu Peterpan sebagai pra-promo kemunculan nama band baru pasca Peterpan dan single hit-nya. Terang saja pada hari kebebasannya, Ariel disambut histeris ratusan - mungkin hampir mencapai ribuan - orang di depan dan di luar rutan layaknya bintang musik dunia.

Bintang adalah aktor/ aktris yang mencapai status luar biasa karena persona atraktif yang diproyeksikannya. Meskipun Burton dalam kasusnya lebih menceritakan bintang film atau dalam ranah Indonesia bisa juga dipahami sebagai pesinetron, namun teorinya ini dapat dikaitan dengan bintang musik atau rock star. Bagaimanapun menjadi persona rock star adalah sebuah capaian yang luar biasa. Pada abad 21 pencapaian menjadi bintang dari jalan murni tanpa sekelumit sensasi yang ditimbulkan amatlah sulit. Dukungan pemberitaan televisi akan sensasi yang dibuat misalnya sedikit membuka jalan menuju popularitas, yang mana televisi merupakan sebuah produk teknologi paling diminati keberadaannya dimasyarakat, contohnya kisah popularitas penyanyi Syahrini.

Burton mendaulat berita sebagai sumber informasi tentang dunia. Secara mikro, dunia berita dalam hal ini adalah kasus Ariel Noah, dan sekelumit kepentingan yang menyertainya, baik kepentingan media itu sendiri maupun artis dan manajemennya. Berita bukan semata-mata dimunculkan secara fakta saja, namun berita dapat dibentuk atau diciptakan. Fakta kasus asusila oleh Ariel memang terjadi di masyarakat, namun sentilan bumbu-bumbu yang diciptakan disertakan dalam pemberitaannya. Mulai dari bahasa, susunan kalimat narasi, bahkan hingga tokoh-tokoh lain yang sengaja dikaitkan, walaupun intensitasnya kurang dari $10 \%$ terhadap kasus, misalnya keterlibatan suami Cut Tari. Suami Cut Tari pada hakikatnya memang tidak ada sangkutpautnya dengan kasus tersebut, namun seakan mental sang suami menjadi perhitungan prioritas tersendiri. Tidak luput juga saah satu media elektronik yang mengkaitkan sosok bintang porno Miyabi. Racikan bumbubumbu ini yang menjadikan orang semakin penasaran akan kelanjutan kisah yang terjadi. 
Manejemen media merancang agenda berita yang dirasa penting atau layak untuk diperbincangkan. Berita tentang Ariel merupakan salah satu dari berita prioritas, dikarenakan berita tentang kasus tokoh publik dirasa cukup berkelas dalam upayanya menarik minat audien. Media dalam hal ini memanfaatkan budaya penggemar sebagai kepentingannya. Terlebih lagi jika media tersebut adalah sebuah progam acara informasi selebritas. Kebutuhan akan data-data yang setiap waktu harus update mengakibatkan media memilih kasus tokoh publik karena kasus tersebut akan menjadi semacam kisah. Berita akan tokoh public yang menjadi sebuah kisah dengan sendirinya terjadi kontinuitas sehingga berdampak pada beberapa pihak yang diuntungkan. Tanpa sebuah praduga, kepentingan atas beragam keuntungan bahkan profit menjadi salah satu esensinya. Kasus Ariel ini sejalan dengan konsep aspek human interest Burton karena memiliki suatu kontinuitas yang menarik untuk konsumsi konsumen media.

\section{Penutup}

Setiap komposisi musik/lagu-lagu pop memiliki kemiripan satu dengan yang lain. Kemiripan tersebut sebagian besar terletak pada susunan tema dan adanya intro sebelum masuknya melodi lirik, termasuk lagu Separuh Aku. Kemiripan tema, lirik dan dan adanya intro pada lagu Separuh Aku dinilai sebagai standarisasi dan individual semu yang sarat kepentingan. Kepentingan ekonomi menjadi sarat utama terciptanya musik ringan tentunya dengan target pencapaian atas popularitasnya.

Sebagian besar konsumen/penikmat musik pop menggunakannya untuk hiburan semata. Dengan lirik yang mudah dipahami, konsumen musik pop memanfaatkannya hanya sebatas teman disaat mengalami kejenuhan. Terlebih lagi jika lirik yang diciptakan bertepatan dengan keadaan psikologis pendengar, maka seakan menjadikan dirinya sebagai bagian dari penciptaan lagu. Hal tersebut meng-akibatkan munculnya sebuah ekspresi atau peluapan perasaan melalui pelafalan atau nyanyian pendengar. Setiap ekspresi yang timbul dari pendengar merupakan upaya penghiburan dirinya. Jika ekspresi tersebut diluapkan di muka publik, maka secara tidak langsung memaksa telinga lain untuk mendengar liriknya. Ini merupakan salah satu sarana musik pop mengembangkan sayapnya.

Jika popularitas musik pop dapat terjadi lewat sarana ekspresi konsumen, maka melalui kekuatan yang lain, yakni media secara signifikan juga ikut dalam menciptakan jalan mulus tersebut. Media sangat leluasa dalam upaya membentuk wacana publik dalam hal ini konsumen/ audien musik pop. Audien musik mencakup pendengar, penikmat, dan penggemar. Penggemar berkaitan dengan yang digemari, dalam kasus ini adalah Ariel. Kasus-kasus seperti Ariel ini menjadi prioritas berita dalam media. Pemberitaan mengenai kehidupan seorang bintang adalah sesuatu yang sangat menarik. Kehidupan bintang terlebih lagi yang terlilit kasus seperti Ariel tersebut mengandung kisah/cerita berkelanjutan. Berita yang berkelanjutan ini lah yang disuguhkan kepada audien dengan harapan ketertarikan audien dalam mengikuti jalannya dan hingga akhir kisahnya.

\section{Referensi}

\section{Buku dan Artikel}

Budiarto, C. Teguh. 2001. Musik Modern dan Ideologi Pasar. Yogyakarta: Tarawang Press.

Burton, Graeme, 2006. Yang Tersembunyi di Balik Media. Yogyakarta: Jala-sutra.

Burton, Graeme. 2012. Media dan Budaya Populer. Yogyakarta, Jalasutra.

Fikri, M. Tsaqibul. 2016. “Kajian Budaya Pop Pada Musik Keroncong: Perkembangan dan Pengaruh Budaya Musik 
Pop." Yogyakarta: Progam Pasca Sarjana ISI Surakarta, dalam www.academia.edu.

Hamidi, 2004. Metode Penelitian Kualitatif: Aplikasi Praktis Pembuatan Proposal dan Laporan Penelitian. Malang: UMM Press.

Hananto, Paulus D. 2011. "Analisis Sonatina Op. 15 Untuk Flute dan Gitar Karya John William Duarte." Dalam Jurnal Musik, Jurnal Ilmiah seni Musik, vol. 2, no. 2/2011, pp 120-147.

Hermintoyo, D. Implikatur Metafora dalam Lirik Lagu Indoneisa Populer: Suatu Kajian Semiotik-Pragmatik. Dalam www.academia.edu.

Kuntjojo. 2009. “Metodologi Penelitian." Materi Diklat. Kediri: Universitas Nusantara PGRI.

Ratna, Nyoman K. 2010. "Metodologi Penelitian: Kajian Budaya dan Ilmuilmu Sosial Humaniora Pada Umumnya." Yogyakarta: Pustaka Pelajar.
Storey, John. 2007. Cultural Studies dan Kajian Budaya Pop. Yogyakarta: Jalasutra.

Strinati, Dominic. 2009. An Introduction to Theories of Popular Culture. London and New York: Routledge.

Strinati, Dominic. 2009. Popular Culture: Pengantar Menuju Teori Budaya Populer. Yogyakarta: Ar- Media Ruzz

\section{Webtografi}

https://id.wikipedia.org/wiki/Separuh_Aku, diambil pada 14 Juni jam 10.15.

http://www.noah-site.com, diambil pada 14 Juni 2015 jam 10.00 .

http://www.republika.co.id/berita/senggang /musik/12/09/11/ma6u54-laguseparuh-aku-noah-tercipta-daricurhat-teman, diambil pada 14 Juni jam 10.10

http://4.bp.blogspot.com/-3ObFD-6hRo/UB4lauZZbqI/AAAAAAAAAVY /eoANSRyQJYo/ s1600/x2_dc0c2d4, diambil pada 14 Juni jam 10.13 